\title{
REJESTR WYZNANIOWYCH OSÓB PRAWNYCH - WYBRANE ZAGADNIENIA NA PRZYKŁADZIE JEDNOSTEK KOŚCIOŁA KATOLICKIEGO
}

WSTĘP

Funkcjonowanie Kościołów i innych związków wyznaniowych w państwowych systemach prawnych wymaga określenia szczegółowych zasad współpracy oraz granic autonomii. Granice te, wypracowywane w Polsce od 1989 r., ciągle wymagają doprecyzowania, zwłaszcza w zakresie funkcjonowania wyznaniowych osób prawnych podlegających dwóm systemom prawnym - państwowemu i wewnętrznemu. Działalność wyznaniowych osób prawnych i ich organów w przestrzeni państwowego prawa i administracji wielokrotnie stawała się tematem orzeczeń sądów powszechnych oraz wypowiedzi doktryny.

W niniejszym artykule przytoczone zostaną argumenty związane z postulatem utworzenia publicznego rejestru wyznaniowych osób prawnych, a także jego zakres i możliwy schemat funkcjonowania. Omówione zostaną również zagadnienia związane $\mathrm{z}$ funkcjonowaniem wyznaniowych osób prawnych na przykładzie parafii Kościo-

* Mgr lic. teolog., student administracji, Filia Uniwersytetu Łódzkiego w Tomaszowie Mazowieckim, ul.Konstytucji 3 Maja 65/67, 97-200 Tomaszów Mazowiecki, e-mail: malesa.w@gmail.com

** Studentka prawa, Wydział Prawa i Administracji, Uniwersytet Jagielloński, ul. Gołębia 24, 31-007 Kraków, e-mail: an.wawrzaszek@gmail.com 
ła katolickiego w zakresie ich tworzenia oraz działania. W Polsce w 2011 r. istniało 10177 parafii katolickich, zaś wierni tego wyznania stanowili 95,5\% ogółu ludności Polski ${ }^{1}$. Zgodnie z konstytucyjną zasadą równouprawnienia Kościołów i innych związków wyznaniowych (art. 25 ust. 1) wszystkie prawa i obowiązki przedstawione w niniejszym artykule w odniesieniu do Kościoła katolickiego i jego jednostek, można zastosować do pozostałych Kościołów i związków wyznaniowych ${ }^{2}$.

\section{OSOBY PRAWNE}

Osobą prawną według prawa polskiego jest jednostka organizacyjna, której prawodawca przyznał osobowość prawną. Należy jednak pamiętać o brzmieniu art. 37 § 1 k.c.: „Jednostka organizacyjna uzyskuje osobowość prawną z chwilą jej wpisu do właściwego rejestru, chyba że przepisy szczególne stanowią inaczej”, z którego wynika, że pojęcia , przyznanie osobowości prawnej” i ,uzyskanie osobowości prawnej” nie są tożsame. Przyznanie przez prawodawcę danej jednostce organizacyjnej osobowości prawnej otwiera dopiero drogę do uzyskania przez nią osobowości prawnej. Tylko wyjątkowo osobowość prawna może być nadana jednostce organizacyjnej przez przepisy szczególne ${ }^{3}$.

Działanie osobom prawnym umożliwiają osoby fizyczne, dlatego konieczne jest ustalenie, kto i w jakim zakresie ma prawo reprezentowania danej jednostki. Powstały dwie teorie reprezentacji osób prawnych. W Polsce przyjęta została teoria organu. Organ jest częścią wewnętrznej struktury osoby prawnej, a jego działania są działaniami samej osoby prawej. Drugą teorią - zyskującą coraz więcej zwolenników - jest teoria przedstawicielstwa. Zakłada ona, że przedstawi-

${ }^{1}$ Wyznania religijne, stowarzyszenia narodowościowe $i$ etniczne w Polsce 2009-2011, red. P. Ciecieląg, Warszawa 2013, s. 36.

${ }^{2}$ Zob. P. Borecki, Zasada równouprawnienia wyznań w prawie polskim, „Studia z Prawa Wyznaniowego" 2007, t. 10, s. 115-116.

${ }^{3}$ Zob. A. Kidyba, Kodeks cywilny. Komentarz. Część ogólna, t. 1, Warszawa 2009, s. $150-151$. 
ciel działa jako osobna jednostka, a jego działania wywierają skutki w majątku osoby prawnej ${ }^{4}$.

Kodeks cywilny nie reguluje ilości, rodzaju czy sposobu powoływania organów - odsyła w tym zakresie do ustaw szczegółowych i statutów poszczególnych jednostek. Organ jest stałym i niezbędnym elementem struktury organizacyjnej osoby prawnej; umożliwia jej dokonywanie nie tylko czynności prawnych, ale także faktycznych, np. zarząd czy kontrola. Jego uprawnienia są więc znacznie szersze niż przedstawiciela (który działa tylko w sferze cywilnoprawnej).

Aby organy mogły odpowiednio reprezentować osobę prawną, musi być spełnionych szereg warunków. Przede wszystkim, powinien powstać katalog określający, jakie organy są uprawnione do reprezentacji oraz jakie są ich kompetencje. Następnie muszą zostać powołane osoby, które będą działać jako organ. Wymagane jest także, by występowały one jako organ (w sposób przynajmniej dorozumiany) oraz działały według zasad przewidzianych w ustawie lub statucie ${ }^{5}$.

Działający skutecznie organ działa w granicach swoich kompetencji. Na gruncie art. 39 k.c. przekroczenie kompetencji powoduje bezwzględną nieważność czynności i brak możliwości jej konwalidacji.

\section{KOŚCIELNE OSOBY PRAWNE WEDŁUG PRAWA PAŃSTWOWEGO}

Większość wyznaniowych osób prawnych w Polsce to jednostki organizacyjne Kościoła katolickiego. Analizę pozycji ustrojowej Kościoła należy rozpocząć od art. 25 ust. 4 Konstytucji RP, który stanowi, że stosunki między Rzecząpospolitą Polską a Kościołem katolickim określają umowa międzynarodowa ze Stolicą Apostolską ${ }^{6}$ oraz ustawy. Ustawą, która określa szczegółowo sytuację prawną tegoż Kościoła jest ustawa z dnia 17 maja 1989 r. o stosunku Państwa do Kościoła Katolic-

${ }^{4}$ Zob. F. Zoll, Prawo cywilne. Część ogólna, Warszawa 2011, s. 227; K.A. Dadańska, Działanie osoby prawnej, Warszawa 2006, s. 26-35.

${ }^{5}$ Zob. K.A. Dadańska, Działanie osoby prawnej, s. 38-80.

${ }^{6}$ Konkordat między Stolicą Apostolską i Rzecząpospolitą Polską podpisany w Warszawie dnia 28 lipca 1993 r., Dz. U. z 1998 r. Nr 51, poz. 318 (dalej: Konkordat). 
kiego w Rzeczypospolitej Polskiej ${ }^{7}$, a w kwestiach w niej nieuregulowanych - ustawa z dnia 17 maja 1989 r. o gwarancjach wolności sumienia i wyznania ${ }^{8}$.

Osobowość prawną zarówno całego Kościoła, jak i jego jednostek organizacyjnych zapewniają postanowienia Konkordatu (art. 4 ust. 1 i 2). Inna jest jednak pozycja Kościoła, a inna jego jednostek. Kościół katolicki wyposażony został w osobowość prawnąa , jednak działać w sferze cywilnej mogą tylko jego jednostki organizacyjne (art. 5-10 u.s.p.k.k).

Charakterystyczne dla kościelnych osób prawnych jest ich funkcjonowanie na gruncie dwóch porządków prawnych - państwowego i kanonicznego. Kościół i Państwo są od siebie niezależne (art. 25 ust. 3 Konstytucji RP i art. 1 Konkordatu). Nie da się jednak całkowicie oddzielić działalności tych podmiotów. Dwa porządki prawne muszą się czasami zazębiać ${ }^{10}$.

Tworzenie właściwych Kościołowi struktur należy do kompetentnej władzy kościelnej (art. 6 ust. 1 Konkordatu). Tylko w celu zapewnienia pewności obrotu polski prawodawca wymienia osoby prawne wchodzące w skład struktury organizacyjnej Kościoła katolickiego oraz ich organy (art. 6-10 u.s.p.k.k.) ${ }^{11}$. Żadna kościelna osoba prawna nie może jednak powstać na mocy prawa polskiego bez wcześniejszego utworzenia jej przez kompetentną władzę kościelną działającą na podstawie prawa kanonicznego.

${ }^{7}$ Tekst jedn. Dz. U. z 2013 r., poz. 1169 z późn. zm. (dalej: u.s.p.k.k.).

${ }^{8}$ Tekst jedn. Dz. U. z 2005 r. Nr 231, poz. 1965 z późn. zm. (dalej: u.g.w.s.w.).

${ }^{9}$ Zob. B. Rakoczy Ustawa o stosunku Państwa do Kościoła Katolickiego w Polsce. Komentarz, Warszawa 2008, s. 55-57. Rakoczy nazywa osobowość prawną Kościoła osobowością publicznoprawną. Odmienne zdanie wyraża G. Radecki, utrzymując, że polskie prawo nie przewiduje takiej osobowości prawnej i mówić można tylko o publicznym statusie Kościoła (G. Radecki, Organy osób prawnych Kościoła katolickiego w Polsce (na styku prawa kanonicznego i prawa cywilnego), „Rejent” 2003, nr 7-8(147-148), s. 133). Zob. także A. Mezglewski, Stolica Apostolska i Państwo Watykańskie jako podmioty prawa międzynarodowego, „Studia z Prawa Wyznaniowego” 2005, t. 8, s. 296-300.

${ }^{10}$ Zob. P. Borecki, Autonomia Kościołów i innych zwiazków wyznaniowych we współczesnym prawie polskim, „Przegląd Religioznawczy” 2011, nr 3, s. 126.

${ }^{11}$ A. Mezglewski, H. Misztal, P. Stanisz, Prawo wyznaniowe, Warszawa 2008, s. 131-136. 
Kościelne jednostki organizacyjne uzyskują osobowość prawną w różny sposób. Z mocy samej ustawy osobowość prawną uzyskały m.in.: Konferencja Episkopatu Polski, Caritas Polska, oraz uczelnie: Katolicki Uniwersytet Lubelski (obecnie: Katolicki Uniwersytet Lubelski Jana Pawła II), Papieska Akademia Teologiczna w Krakowie (obecnie: Uniwersytet Papieski Jana Pawła II w Krakowie), Papieski Wydział Teologiczny we Wrocławiu, Papieski Wydział Teologiczny w Warszawie wraz ze swoimi dwoma ,sekcjami”: św. Jana Chrzciciela i św. Andrzeja Boboli i inne. Jednostki niewymienione w ustawie mogą na mocy art. 10 u.s.p.k.k. uzyskać osobowość prawną w drodze rozporządzenia właściwego ministra ${ }^{12}$. Z kolei jednostki wymienione w ustawie według rodzaju (parafie, zakony itp.) uzyskują osobowość prawną z chwilą utworzenia ich przez kompetentną władzę kościelną, przy czym ma ona obowiązek powiadomienia właściwego organu administracji publicznej o ich utworzeniu ${ }^{13}$.

\section{PRAKTYKA ZGŁASZANIA KOŚCIELNYCH OSÓB PRAWNYCH}

Dla omawianego zagadnienia istotny będzie tryb uzyskiwania osobowości prawnej przez jednostki Kościoła katolickiego wskazany $\mathrm{w}$ art. 13 u.s.p.k.k. Według wskazanej procedury, jednostka organizacyjna Kościoła (na przykład parafia czy diecezja) otrzymuje osobowość prawną na gruncie prawa kanonicznego z chwilą jej utworzenia, zaś prawo państwowe uznaje tę osobowość i włącza jednostkę w system prawa państwowego ${ }^{14}$. M. Pietrzak określa ten system jako „deklaracyj-

${ }^{12}$ Co świadczy o tym, że katalog zawarty w u.s.p.k.k. nie jest zamknięty.

${ }^{13}$ Zob. J. Krukowski, K. Warchałowski, Polskie prawo wyznaniowe, Warszawa 2000, s. 110-113. Jednostki figurujące w ostatnim schematyzmie wydanym drukiem przed wejściem w życie ustawy, ankiecie statystycznej zakonu z dnia 31 grudnia 1988 r. lub legitymujące się decyzją o niezgłoszeniu zastrzeżeń przeciwko utworzeniu parafii ustawy uzyskały osobowość prawną bez wymogu ich zgłaszania.

${ }^{14}$ Zob. G. Radecki, Organy osób prawnych, s. 129; M. Plisiecki, Wyznaniowa osoba prawna $w$ prawie polskim, Warszawa 2013, s. 99-100; W. Góralski, A. Pieńdyk, Zasada niezależności i autonomii Państwa i Kościoła w Konkordacie polskim z 1993 r., Warszawa 2000, s. 26-27; M. Pietrzak, Prawo wyznaniowe, Warszawa 2010, s. 274-277. 
no-informacyjny"15. Uznanie osobowości prawnej - zgodnie z przepisem ustawy - dokonuje się w chwili przedłożenia stosownej informacji do właściwego organu administracyjnego. Dowodem tej czynności jest odpis powiadomienia z poświadczeniem odbioru ${ }^{16}$.

Organy państwowe przyjmują do wiadomości najważniejsze informacje związane z powstawaniem wyznaniowych osób prawnych i zmianach w ich strukturze (zob. art. 13 u.s.p.k.k.). W wyniku ustaleń komisji konkordatowej stworzono dokumenty określające formę wzajemnej współpracy Państwa i Kościoła w omawianym zakresie ${ }^{17}$. Ustalone zostały w nich m.in. wzory powiadomień o uzyskaniu osobowości prawnej przez instytucje kościelne, potwierdzeń odbioru powiadomienia oraz wykaz kompetencyjny określający organy właściwe do podejmowania działań.

Praktyka administracyjna wskazuje, że - pomimo jasnych wytycznych ze strony rządowej i kościelnej - powiadomień dokonują często osoby do tego nieumocowane. Przykładowo, o utworzeniu lub zniesieniu parafii katolickich oraz o zmianach dotyczących organów parafii właściwy biskup diecezjalny powiadamia właściwego wojewodę. W praktyce powiadomienia tego dokonują np. kanclerz kurii (kuria nie jest w świetle prawa państwowego organem diecezji, a kanclerz z samej mocy prawa kanonicznego nie jest pełnomocnikiem biskupa) lub sam mianowany proboszcz ${ }^{18}$.

${ }^{15}$ Zob. M. Pietrzak, Prawo wyznaniowe, Warszawa 2005, s. 260.

${ }^{16}$ Zob. B. Rakoczy, Ustawa o stosunku państwa do Kościoła, s. 112-119.

${ }^{17}$ Zob. Instrukcja dotyczaca sposobu powiadamiania organów państwowych o uzyskaniu osobowości prawnej przez instytucje kościelne terytorialne i personalne (art. 4 ust. 2 Konkordatu) oraz powiadamiania o powotywaniu i odwoływaniu osoby sprawujacej funkcje organu osoby prawnej, stanowiąca załącznik do obwieszczenia Ministra Spraw Zagranicznych z dnia 27 listopada 2014 r. (Dz. Urz. MSZ z 2014 r., poz. 30), która zastąpiła w całości Instrukcję z dnia 13 marca 2000 r. dotycząca sposobu powiadamiania organów państwowych o uzyskaniu osobowości prawnej przez terytorialne i personalne instytucje kościelne, art. 4 ust. 2 Konkordatu, (Akta Konferencji Episkopatu Polski, nr 4, Warszawa 2000, s. 35-40); Instrukcja z dnia 15 czerwca 2000 r. dotyczaca zakresu i sposobu uzyskania osobowości pranej przez instytucje kościelne na podstawie prawa polskiego (art. 4 ust. 3 Konkordatu), https://mac.gov.pl/files/wp-content/uploads/2013/09/instrukcja-dotyczacaart-4-ust-3.pdf [dostęp: 21.08.2014]; zob. także: D. Walencik, Opinia prawna $w$ sprawie nabycia osobowości prawnej przez dom zakonny Zgromadzenia Sióstr Najświętszej Rodziny z Nazaretu z siedziba w Żarkach, „Przegląd Prawa Wyznaniowego” 2011, nr 3, s. 259-260.

${ }^{18}$ Dane pozyskane od pracowników urzędów wojewódzkich w styczniu i lutym 2014 r. na podstawie prawa dostępu do informacji publicznej. 
Rodzi się pytanie o skuteczność powiadomienia dokonanego przez niewłaściwy organ lub niezawierającego wymaganych dokumentów (np. dekretu nominacyjnego) poświadczających wolę biskupa diecezjalnego.

W prawie polskim brakuje regulacji dotyczacych sposobu działania organów kościelnych osób prawnych oraz ich kompetencji. Brakuje też jednoznacznego wskazania, gdzie znajdują się właściwe przepisy regulujące omawiane zagadnienie. Wysnuć można z tego wniosek, że organy tych osób są w pełni kompetentne do działania w ich imieniu i nie mają $\mathrm{w}$ tym zakresie żadnych ograniczeń. W świetle prawa kanonicznego wygląda to jednak inaczej.

\section{OGRANICZENIA REPREZENTACJI WYNIKAJACE Z PRAWA} KANONICZNEGO

Ogólną zasadą uzyskiwania osobowości prawnej przez zespół osób (na przykład stowarzyszenia) lub rzeczy (czyli fundacje autonomiczne) jest na gruncie Kodeksu Prawa Kanonicznego (dalej: KPK) nadanie tejże osobowości przez przepis prawa kanonicznego (mocą samego prawa) lub przez kompetentną władzę kościelną w formie dekretu.

Charakterystycznymi jednostkami kościelnymi posiadającymi osobowość prawną są Kościoły partykularne. KPK wymienia wśród nich diecezje, prałatury terytorialne, opactwa terytorialne, wikariaty apostolskie, prefektury apostolskie oraz administratury apostolskie erygowane na stałe (kan. $368 \mathrm{KPK}$ ). Wszystkie one posiadają osobowość prawną z mocy samego prawa, o ile są erygowane zgodnie z obowiązującymi normami prawa kanonicznego przez kompetentną do tego władzę kościelną. Kolejną jednostką terytorialną posiadającą osobowość prawną z mocy samego prawa kanonicznego jest parafia, na czele której stoi zazwyczaj proboszcz. Podstawowe zadania i obowiązki proboszcza określają przepisy kanoniczne. Kodeks określa także ogólne granice kompetencji proboszcza w stosunku do sprawowania zarządu dobrami doczesnymi Kościoła (zob. kan. 528-532 KPK). KPK wskazuje, że ,zarządca” danej osoby prawnej może działać w granicach ,zwyczajnego zarządzania”, które powinny być określone w statu- 
tach ${ }^{19}$. W przypadku braku statutów do biskupa diecezjalnego należy sprecyzowanie pojęcia zwykłego zarządu (kan. 1281 KPK). Do kompetencji konferencji episkopatu należy ustalenie wartości dóbr, których alienacja $^{20}$ w świetle prawa kanonicznego wymaga zgody biskupa diecezjalnego lub Stolicy Apostolskiej. Dokonanie przez proboszcza alienacji przedmiotu o wartości przekraczającej kwotę ustaloną przez episkopat bez zgody biskupa diecezjalnego (lub odpowiednio Stolicy Apostolskiej) stanowi naruszenie przepisów prawa kanonicznego (kan. 1291-1292 KPK) ${ }^{21}$.

B. Rakoczy zwraca uwagę na istotne zagadnienie wynikające z treści kan. 1377: „Kto alienuje dobra kościelne bez przepisanego prawem zezwolenia, powinien być ukarany sprawiedliwą karą." Prawodawca kościelny ma świadomość, że alienacja może skutecznie nastąpić na gruncie prawa państwowego, zaś do odpowiedzialności kanonicznej zostanie pociągnięta osoba, działająca niezgodnie z przepisami kościelnymi ${ }^{22}$.

Pojawiają się wątpliwości związane z rozumieniem stosowanego w prawie kanonicznym terminu ,zwykły zarząd” (kan. $1281 \mathrm{KPK}$ ), do którego sprawowania upoważniony jest proboszcz parafii. Dla

${ }^{19}$ Zarządcy dóbr doczesnych Kościoła nie powinni także wszczynać sporów przed sądami państwowymi w imieniu osób prawnych bez zgody właściwego biskupa diecezjalnego (kan. 1288 KPK).

${ }^{20}$ Pojęcie alienacji nie zostało określone w Kodeksie Prawa Kanonicznego. W doktrynie wskazuje się, że alienacją jest czynność prawna, na mocy której własność danego dobra przechodzi na inny podmiot (np. sprzedaż, darowizna, zamiana). Termin ,alienacja” bywa także używany do określenia czynności, które pogarszają sytuację kościelnej osoby prawnej (np. ustanowienie hipoteki, służebności, zastawu). Zob. A. Januchowski, Wybrane zagadnienia, s. 214; S. Dubiel, Uprawnienia majątkowe Kościoła katolickiego w Polsce w świetle Kodeksu prawa kanonicznego z 1983 roku, Konkordatu z 1993 roku i ustaw synodalnych, Lublin 2007, s. 73.

${ }^{21}$ W 2006 r. Stolica Apostolska zatwierdziła kwoty ustalone przez Konferencję Episkopatu Polski. Według tych przepisów, dla ważności czynności prawnej, której kwota przekracza równowartość 100.000 euro wymagana jest zgoda biskupa diecezjalnego, zaś dla czynności, której wartość przekracza równowartość 1.000.000 euro - zgoda Stolicy Apostolskiej. Zob. A. Januchowski, Wybrane zagadnienia zwiąane z reprezentacja parafii przez proboszcza na gruncie prawa kanonicznego i polskiego, „Studia z Prawa Wyznaniowego” 2008, t. 11, s. 213.

${ }^{22}$ Zob. B. Rakoczy, Odpowiedzialność zakonnika załatwiajacego sprawy zakonnej osoby prawnej, „Przegląd Prawa Wyznaniowego” 2009, nr 1, s. 68-69. 
przykładu wskazać można przepisy partykularnego prawa kanonicznego obowiązującego w Archidiecezji Łódzkiej, zawartego w Statutach III Synodu Archidiecezji Łódzkiej ${ }^{23}$. Zgodnie z nimi, zarządcą wszelkich kościelnych dóbr materialnych na terenie Archidiecezji jest Arcybiskup Łódzki (art. 329). Proboszcz lub administrator parafii zarządza nimi w jego imieniu (art. 331). Prawo partykularne Kościoła łódzkiego zabrania proboszczom sprzedaży, dzierżawy, ustanawiania użytkowania, zamiany, darowizn, obciążania lub innych sposobów alienacji majątku kościelnego bez zezwolenia właściwego arcybiskupa (art. 335). Kapłani diecezjalni nie mają także prawa zaciągania długów, podpisywania weksli oraz żyrowania pożyczek na jakiekolwiek cele parafialne lub prywatne (art. 344).

KPK wielokrotnie nakazuje przestrzeganie przepisów państwowych. Zalecenia takie dotyczą m.in. przyjmowania darowizn, zawierania umów o pracę, zabezpieczenia własności majątku kościelnego itd. Szczególną uwagę zwraca na to treść kan. 1290: „To, co prawo państwowe na danym terytorium postanawia odnośnie do umów (...) oraz zobowiązań, ma być zachowywane również mocą prawa kanonicznego w odniesieniu do rzeczy podlegających władzy rządzenia Kościoła, z tymi samymi skutkami, chyba że są przeciwne prawu Bożemu lub co innego zastrzega prawo kanoniczne (...)".

\section{PRZYKŁADY ORZECZEŃ ZWIĄZANYCH Z BRAKIEM SPÓJNOŚCI DWÓCH PORZĄDKÓW PRAWNYCH}

Ze względu na brak spójności pomiędzy prawem polskim a prawem kanonicznym, reprezentacja kościelnych osób prawnych stała się kwestią sporną w wielu sprawach zawisłych przed sądami państwowymi. W doktrynie pojawia się pogląd, że „niezupełność” regulacji na gruncie państwowym, oceniana w świetle założenia racjonalności polskiego prawodawcy, prowadzi do konieczności stosowania norm prawa wewnętrznego związków wyznaniowych w sytuacjach nieure-

${ }^{23}$ Zob. III Synod Archidiecezji Łódzkiej, Łódź 1999. 
gulowanych prawem państwowym ${ }^{24}$. Orzecznictwo Sądu Najwyższego uznawało obowiązywanie prawa kanonicznego, lecz z różnymi uzasadnieniami ${ }^{25}$. Dwa orzeczenia dotyczące działania proboszczów bez odpowiedniego umocowania na tle prawa kanonicznego odegrały kluczową rolę w kwestii uregulowania sposobu reprezentacji kościelnych osób prawnych. Pierwszy z nich to wyrok Sądu Najwyższego $\mathrm{z}$ dnia 27 lipca $2000 \mathrm{r}^{26} \mathrm{~W}$ jego sentencji SN orzekł, że zawarcie przez proboszcza umowy kredytu bez zezwolenia biskupa było przekroczeniem uprawnień organu, co prowadzi do bezwzględnej nieważności dokonanej czynności prawnej.

Zgodnie z prawem kanonicznym ${ }^{27}$ zgoda taka była wymagana. Wątpliwości budzi jednak samo zastosowanie tego prawa. W uzasadnieniu wyroku SN wskazuje, że ustrój osoby prawnej musi być uregulowany w sposób mocny i jawny. Art. 35 k.c. odsyła do ustaw lub statutów w zakresie przewidzianym w ustawie. Na mocy art. 38 k.c. osoby prawne działają poprzez swoje organy, lecz sposób ich działania także musi zostać szczegółowo uregulowany. W omawianej sprawie sposób działania organu powinien zostać określony w u.s.p.k.k. ${ }^{28}$ Ustawa jednak nie zawiera takich regulacji. SN utrzymuje, że ze względu na autonomię Kościoła jedyną kompetentną władzą do uregulowania tej kwestii jest władza kościelna, a przepisami właściwymi - regulacje prawa kanonicznego. Podstawą dla takiego wniosku stał się dla SN art. 2 u.s.p.k.k. Artykuł ten wyraża jednak przede wszystkim zasadę samorządności Kościoła i jego niezależności od państwa. Dotyczy wewnętrznych spraw Kościoła, a kwestia reprezentacji osób prawnych jest istotna także dla osób trzecich ${ }^{29}$. Ustawa nie

${ }^{24}$ Zob. D. Walencik, Opinia prawna, s. 263; P. Stanisz, Proboszcz jako reprezentant parafii rzymskokatolickiej w stosunkach cywilnoprawnych, w: Prawo państwowe a prawo wewnętrzne związów wyznaniowych. Pamiętnik VII Zjazdu Katedr i Wykładowców Prawa Wyznaniowego, Gniezno 11-12 IX 2010, red. K. Krasowski, M. Materniak-Pawłowska, M. Stanulewicz, Poznań 2010, s. 199.

${ }^{25}$ Zob. J. Gliszczyńska-Gniewek, M. Śliwińska, Zawieranie umów w praktyce bankowej. Parafia Kościoła katolickiego, Poznań 2012, s. 18-22

${ }^{26}$ Sygn. akt IV CKN 88/00, OSP 2003, z. 9, poz. 115.

${ }^{27}$ Zob. kan. 638 § 1 i 3 oraz kan. $1281 \S 1$ KPK.

${ }^{28}$ Stan faktyczny sprawy z 1992 r., a więc sprzed wejścia w życie Konkordatu.

${ }^{29}$ Zob. wyrok SN, sygn. akt IV CK 108/03. 
zawiera także odesłania do prawa kanonicznego, zaś art. 3 stanowi, że w sprawach nieuregulowanych stosuje się przepisy prawa powszechnie obowiązującego ${ }^{30}$.

Jak zauważył M. Pietrzak ${ }^{31}$, SN wymagał znajomości prawa kanonicznego od pracowników banku, jednocześnie nie zwracając uwagi na to, że to strona kościelna powinna przestrzegać swojego prawa. Należy się więc zgodzić z autorem, iż miało miejsce naruszenie równości stron, a proboszcz (którego niewątpliwie prawo kanoniczne obowiązuje) działał poza swoimi kompetencjami. W wyniku orzeczenia SN, strona, która nie przestrzegała własnych przepisów, odniosła korzyść, pokrzywdzona została natomiast strona przeciwna - działająca w dobrej wierze i zaufaniu do kontrahenta.

Wątpliwości budzi też jawność prawa kanonicznego ${ }^{32}$. Nie zostało ono opublikowane, jak powszechnie obowiązujące akty prawne, gdyż nie należy do źródeł prawa wymienionych w art. 87 Konstytucji RP. W związku z powyższym nie można na nikogo nakładać obowiązku znajomości tego prawa, a jego nieznajomość nie może szkodzić. Prawo kanoniczne jest prawem wewnętrznym Kościoła katolickiego i stanowi raczej odpowiednik statutu pozostałych osób prawnych ${ }^{33}$, jednakże założenia statutów odnośnie do kompetencji organów podlegają publikacji na drodze wpisu do właściwego rejestru ${ }^{34}$. Dla kościelnych osób prawnych rejestr taki nie został utworzony, a osoby trzecie zawierające umowy z kościelnymi osobami prawnymi nie mają dostępu do zakresu kompetencji poszczególnych organów.

${ }^{30}$ Zob. M. Pietrzak, Prawo kanoniczne w polskim systemie prawnym, „Państwo i Prawo” 2006, z. 8, s. 16-30.

${ }^{31}$ Tamże.

${ }^{32}$ Zob. A. Januchowski Skuteczność prawa kanonicznego w zakresie reprezentacji osób prawnych Kościoła Katolickiego, „Rejent” 2007, nr 9, s. 53-55. W dodatku o wymogu jawności wspomniał nawet w uzasadnieniu wyroku orzekający skład SN.

${ }^{33}$ Choć ustawa o stosunku Państwa do Kościoła katolickiego posługuje się pojęciem statutu tylko w odniesieniu do poszczególnych jednostek organizacyjnych Kościoła i, jak zauważa M. Plisiecki (Wyznaniowa osoba prawna, s. 157-158), trudno za statut w rozumieniu cywilnoprawnym uznać prawo kanoniczne - odnoszące się do całego Kościoła.

${ }^{34}$ Zob. A. Januchowski, Skuteczność prawa kanonicznego, s. 55; art. 8 i 8 a ustawy o Krajowym Rejestrze Sądowym (tekst jedn. Dz. U. z 2013 r., poz. 1203 z późn. zm.). 
Podobnie jak w wyroku IV CKN 88/00, Sąd Najwyższy orzekł 12 maja 1997 r. $^{35}$, podając jednak inną podstawę zastosowania prawa kanonicznego. W wyroku tym sąd wskazuje statut („konstytucję”) kongregacji jako podstawę do określenia zakresu kompetencji jej organów. Wniosek ten wywodzi jednak z art. 28 ust. 2 u.g.w.s.w. Uzasadnienie to wydaje się nietrafione ze względu na art. 18 tejże ustawy, z którego wynika, iż art. 28 nie ma zastosowania do Kościoła katolickiego, gdyż jego sytuacja została uregulowana w odrębnej ustawie (tj. u.s.p.k.k.) ${ }^{36}$. W wyroku tym SN podkreśla jednakże jeszcze jedną ważną kwestię - kościelne osoby prawne działają przez swoje organy; nie ma możliwości przyjęcia, że są one reprezentowane przez przedstawiciela ustawowego ${ }^{37}$. Taka sytuacja byłaby możliwa, tylko gdyby działanie organów zostało zawieszone.

Drugim ważnym orzeczeniem Sądu Najwyższego jest wyrok z dnia 24 marca $2004 \mathrm{r}^{38} \mathrm{~W}$ nim także SN uznał kompetencje proboszcza do reprezentowania parafii $\mathrm{w}$ stosunkach majątkowych $\mathrm{z}$ osobami trzecimi w sposób i na zasadach określonych w prawie kanonicznym. Podkreślił jednak, że prawo kanoniczne może wywoływać skutki w określonej sferze państwowego porządku prawnego tylko wyjątkowo, gdy państwo wyrazi taką wolę w ustawie lub umowie międzynarodowej. Jednocześnie podstawę do zastosowania prawa kanonicznego wywiódł z innych przepisów ${ }^{39}$ - zastosował art. 35 i 38 k.c. w związku z art. 3 oraz 5-14 u.s.p.k.k. Ustawa przyznaje Kościołowi kompe-

${ }^{35}$ Sygn. akt II CKN 24/97, Lex, nr 80725.

${ }^{36}$ Zob. Wyrok SN, IV CK 108/03.

${ }^{37}$ Zastosowanie teorii przedstawicielstwa postulował M. Krzemiński (Znaczenie prawa kanonicznego dla określenia sposobu reprezentacji kościelnych osób prawnych. Glosa do wyroku SN z 27 lipca 2000 r., IV CK 88/00, „Prawo Bankowe” 2005, nr 10, s. 21-30) ze względu na brak pojęcia organu w prawie kanonicznym. Jednak osoby reprezentujące kościelne jednostki organizacyjne w ustawie o stosunku Państwa do Kościoła katolickiego nazwane są bezpośrednio organami, a teoria organu jest obowiązująca w polskim porządku prawnym. Z poglądem wyrażonym przez SN zgadza się także A. Januchowski (zob. A. Januchowski, Prawo kanoniczne a reprezentacja osób prawnych Kościoła Katolickiego - problem przedstawicielstwa ustawowego i pelnomocnictwa, „Prawo Bankowe” 2008, nr 1, s. 81-90).

${ }^{38}$ Sygn. akt IV CK 108/03, OSN Izba Cywilna, 2005, z. 4, poz. 65.

${ }^{39}$ Na niejasność wywodów SN zwraca uwagę M. Plisiecki (Wyznaniowa osoba prawna, s. 160) 
tencje odnośnie do powoływania swoich osób prawnych (z jedynym wymogiem zgłoszenia ich powstania), a także wskazywania piastunów poszczególnych organów. Z tego SN wnioskuje, że w obliczu braku przepisów ustawowych odnośnie do sposobu reprezentacji kościelnych osób prawnych, prawodawca pozostawił to zagadnienie do uregulowania władzy kościelnej ${ }^{40}$.

Dalej SN podkreślił, że w związku z powyższym prawo kanoniczne powinno być traktowane na równi z ustawami, a nie statutami. Wynikać ma z tego, iż przy ocenie skuteczności działania organu należy brać pod uwagę nie tylko ustawy i prawo kanoniczne, ale także statuty wydane na jego podstawie. Jest to twierdzenie kontrowersyjne ze względu na obowiązujący na mocy Konstytucji RP zamknięty katalog źródeł prawa.

Wszystkie powyższe orzeczenia zostały wydane odnośnie do czynności prawnych dokonanych przed wejściem w życie Konkordatu, co słusznie zauważył SN w uchwale z dnia 19 grudnia 2008 r. ${ }^{41} \mathrm{~W}$ uchwale tej rozstrzygając zagadnienie prawne SN stwierdził, że sprzedaż nieruchomości przez kościelną osobę prawną (w tym przypadku stowarzyszenie) osobie świeckiej bez wymaganego w prawie kanonicznym zezwolenia właściwej władzy kościelnej stanowi czynność prawną niezupełną (na mocy art. 63 k.c.).

Rozstrzygając kwestię obowiązywania wewnętrznych norm kościelnych, SN słusznie zwrócił uwagę na wielość poglądów wyrażanych w tej materii przez doktrynę - bezwzględna konieczność przestrzegania tych norm, całkowite oddzielenie prawa kanonicznego od cywilnego, kwalifikowanie nieumocowanego na gruncie prawa kanonicznego organu jako falsus procurator.

SN podkreślił, że nie ma wątpliwości, iż normy prawa kanonicznego dotyczące alienacji dóbr kościelnych mają moc obowiązującą jedynie w porządku kościelnym, bowiem ich skuteczność w państwowym porządku prawnym jest uzależniona od uznania przez państwo. $\mathrm{W}$ związku jednak $\mathrm{z}$ brakiem odpowiednich regulacji $\mathrm{w}$ prawie państwowym, również w tym przypadku SN zgodził się, że należy uznać obowiązywanie prawa kanonicznego na gruncie komentowane-

${ }^{40}$ Nie zgadza się z tym A. Januchowski (Skuteczność prawa kanonicznego, s. 64).

${ }^{41}$ Sygn. akt III CZP 122/08, OSP 2010, z. 2, poz. 18. 
go zagadnienia. Podstawę do tego wniosku dają art. 35 i 38 k.c., art. 10 u.s.p.k.k. oraz art. 4 (przyznanie osobowości prawnej Kościołowi i jego instytucjom) i 19 (prawo wiernych do zrzeszania się zgodnie z prawem kanonicznym) Konkordatu. Ostatni przywołany przepis stanowi także, że jeśli zrzeszenia kościelne wkraczając w sferę uregulowaną w prawie polskim, podlegają temu prawu, z czego wnioskować należy, iż w kwestiach nieuregulowanych prawem powszechnym podlegają prawu kanonicznemu. Per analogiam, w związku z brakiem regulacji odnośnie do sposobu działania instytucji kościelnych, SN przyjął obowiązywanie prawa kanonicznego ${ }^{42}$.

Ciekawym aspektem przywoływanej uchwały SN jest wyprowadzenie wniosku o czynności prawnej niezupełnej. Sąd podnosi, że wymóg zgody właściwej władzy kościelnej nie może być kwalifikowany jako konieczność zgody innego organu osoby prawnej. Ze statusu ordynariusza $^{43}$ wywodzi wniosek, iż jest on organem nadrzędnym osoby prawnej, usytuowanym poza jej strukturą organizacyjną, pełniącym funkcje nadzorcze. Zachodzi więc sytuacja podobna do uregulowanej w art. 63 k.c. (wymóg zgody osoby trzeciej). Jednak wymóg ten musiałby wynikać z ustawy, co nie ma miejsca w regulacji dotyczącej Kościoła katolickiego, a KPK nie ma charakteru ustawy ${ }^{44}$.

Argumentacja SN (mniej lub bardziej trafna) nie jest przekonują$\mathrm{ca}^{45}$, bowiem żaden przepis prawa polskiego nie wskazuje bezpośrednio na prawo kanoniczne jako właściwe w zakresie regulacji kompetencji organów osób prawnych Kościoła. Nie występuje również wskazanie, że regulacje te zostały zawarte w prawie kanonicznym. W związku z powyższym należałoby przyjąć, iż w świetle prawa polskiego nie ma podstaw do respektowania wymogów prawa kanoniczego ${ }^{46}$.

Ze względów funkcjonalnych nie dziwi jednak linia orzecznicza SN - zakres kompetencji i sposób działania organów osób prawnych musi być w jakiś sposób uregulowany. Konieczne staje się zatem odwołanie

${ }^{42}$ Zob. D. Walencik, Opinia prawna, s. 263.

${ }^{43}$ Zob. kan. 1276 § 1 oraz kan. 1279 § 1 i 2 KPK.

${ }^{44}$ M. Plisiecki, Wyznaniowa osoba prawna, s. 169.

${ }^{45} \mathrm{O}$ czym świadczy brak jednorodnego stanowiska doktryny.

${ }^{46}$ Zob. G. Radecki, Organy osób prawnych; A. Januchowski, Skuteczność prawa kanonicznego. 
do wewnętrznych przepisów kościelnych. Nie można jednak zapominać, że informacje te są kluczowe dla osób wchodzących w stosunki (najczęściej na gruncie majątkowym) z kościelnymi osobami prawnymi. Dlatego też należy zapewnić tym osobom dostęp do informacji, kto i w jakim zakresie może reprezentować daną jednostkę kościelną. Postulowaną formą rozwiązania niewątpliwego problemu rodzącego się na styku dwóch porządków prawnych jest stworzenie rejestru wyznaniowych osób prawnych obejmującego informacje o wszystkich działających w Polsce konfesyjnych osobach prawnych, w szczególności parafiach, zborach, diecezjach, stowarzyszeniach itd. Rozwiązanie takie wypracowali i postulowali między innymi M. Pietrzak, D. Walencik i A. Januchowski ${ }^{47}$.

\section{POSTULAT STWORZENIA PUBLICZNEGO REJESTRU - HISTORIA}

I UZASADNIENIE PROJEKTU

Określenie zakresu kompetencji organów kościelnych osób prawnych wymaga dokonania rozróżnienia na działalność w sferze wewnętrznej oraz zewnętrznej. O ile pierwszy przypadek rozumiany jest jako działalność organu wobec wyznawców danej religii, o tyle w drugim aspekcie pojawia się konieczność określenia zakresu uprawnień poszczególnych organów do reprezentacji osób prawnych na gruncie prawa państwowego. Autonomia gwarantowana przez polskie prawo wyznaniowe Kościołom i innym związkom wyznaniowym dotyczy bez wątpienia sfery organizacji wewnętrznej. Skierowanie działalności wyznaniowej osoby prawnej na forum externum wymaga właściwego umocowania jej organu. M. Plisiecki twierdzi, że „reguły reprezentacji ujęte w prawie wewnętrznym mogą być uznawane za obowiązujące w prawie państwowym jedynie wtedy, gdy stanowią zarazem normy prawa państwowego"48. M. Pietrzak z kolei stwierdza, że ingerencja

${ }^{47}$ Zob. M. Pietrzak, Prawo kanoniczne, s. 31; D. Walencik, Opinia prawna, s. 168; A. Januchowski, Skuteczność prawa kanonicznego, s. 56-57; tenże, Wybrane zagadnienia, s. 234-235.

${ }^{48}$ M. Plisiecki, Wyznaniowa osoba prawna, s. 155. 
sądów państwowych „w kontrolę przestrzegania prawa kanonicznego przez organy i funkcjonariuszy kościelnych (...) naruszałaby gwarantowaną przez konstytucję autonomię i niezależność kościołów. Do takiej kontroli uprawnione są wyłącznie zwierzchnie organy kościelne"49.

Brak dostępności i jasnej interpretacji przepisów prawa kanonicznego $^{50}$ utrudnia określenie prawidłowości umocowania konkretnych osób piastujących funkcje organów osób prawnych oraz ustalenie zakresu kompetencji wynikających $\mathrm{z}$ prawidłowego umocowania. Ponadto żaden przepis prawa państwowego nie nakłada na obywateli polskich obowiązku zaznajomienia się z przepisami prawa kanonicznego, którego treść nie ogranicza się jedynie do Kodeksu Prawa Kanonicznego (w prawie kanonicznym funkcjonuje także Kodeks Kanonów Kościołów Wschodnich, dokumenty papieskie, soborowe i synodalne, przepisy liturgiczne itd. $)^{51}$. Ujawnienie wewnętrznych ograniczeń reprezentacji $\mathrm{w}$ publicznym rejestrze, z którym ustawa zwiąże domniemanie powszechnej znajomości, skutkować będzie również wobec osób trzecich, podejmujących czynności prawne z jednostkami wyznaniowymi ${ }^{52}$.

W obecnej sytuacji kompetentna władza kościelna dokonuje powiadomienia właściwego organu administracji państwowej o działaniach związanych z podległymi jej wyznaniowymi osobami prawnymi oraz mianowaniem lub odwoływaniem osób pełniących funkcję organów tychże jednostek. Organy publiczne nie mają obowiązku gromadzić danych, tworzyć ich zestawień, a tym bardziej znać kompetencji organów wyznaniowych, nawet jeśli te zostałyby wskazane w kościelnych dekretach nominacyjnych, których kopie zostają przedstawione

${ }^{49}$ M. Pietrzak, Prawo kanoniczne, s. 29; A. Januchowski, Skuteczność prawa kanonicznego, s. 59.

${ }^{50}$ Niniejsze rozważania koncentrują się na działaniu parafii rzymskokatolickich, działających w granicach wyznaczanych im przez Kodeks Prawa Kanonicznego. O ile jeszcze Kodeks ten jest dostępny zarówno w Internecie, jak i księgarniach w większych miastach, o tyle Kodeks Kanonów Kościołów Wschodnich tak dostępny już nie jest. Prawie zupełnie niedostępne zdają się być przepisy wewnętrzne Kościołów i związków wyznaniowych działających na podstawie ustawy z dnia 17 maja 1989 r. o gwarancjach wolności sumienia i wyznania i wpisanych do Rejestru kościołów i innych związków wyznaniowych.

${ }^{51}$ Zob. A. Januchowski, Skuteczność prawa kanonicznego, s. 54.

${ }^{52}$ Zob. tenże, Wybrane zagadnienia, s. 217. 
administracji państwowej. Co za tym idzie - w chwili obecnej (na gruncie tylko administracji państwowej) nie ma możliwości otrzymania dokumentu potwierdzającego granice kompetencji organów jednostek wyznaniowych. Warto także zwrócić uwagę, że - w odróżnieniu od organów administracyjnych podległych przepisom państwowym o postępowaniu administracyjnym - jednostki kościelne nie mają obowiązku udzielania informacji o kompetencjach swoich organów lub organów jednostek podległych ${ }^{53}$.

Zgodnie $\mathrm{z}$ prawem kanonicznym oraz statutami synodalnymi poszczególnych diecezji, w określonych okolicznościach w imieniu kościelnych osób prawnych działać mogą także osoby, które w polskim systemie prawnym nie zostały umocowane jako organy - na przykład wikariusze, administratorzy itd. Pojawia się zatem wątpliwość dotycząca skuteczności ich działania na forum publicznym, zakładając brak dodatkowego umocowania do dokonywania czynności prawnych na przykład w formie pełnomocnictwa ${ }^{54}$. Skoro u.s.p.k.k. nie sankcjonuje reprezentacji osób prawnych Kościoła katolickiego przez inne osoby niż wymienione w ustawowym katalogu, znaczy to, że państwo nie przewiduje możliwości odniesienia do prawa kanonicznego i wyprowadzania stamtąd kompetencji do reprezentowania osób prawnych przez inne osoby niż wymienione w ustawie ${ }^{55}$.

Skuteczność działania organów osób prawnych zależna jest od prawidłowości obsadzenia tego organu. Państwo jednak nie ma żadnych podstaw do badania prawidłowości nominowania organów kościelnych osób prawnych. Przyjąć musi za pewnik dokumenty odpowiednich władz dotyczące obsadzenia organów osób prawnych ${ }^{56}$. Przyjęcie

${ }^{53}$ Zob. tenże, Skuteczność prawa kanonicznego, s. 57.

${ }^{54}$ Działanie pełnomocnika niezgodnie z intencją mocodawcy lub działanie przekraczające granice umocowania może mieć konsekwencje dwojakiego rodzaju - wobec mocodawcy oraz wobec osób trzecich. Wydaje się, że w znacznej części przypadków wyznaniowych osób prawnych, konsekwencje wobec mocodawcy będą rozstrzygane na gruncie dwóch porządków prawnych: państwowego oraz wewnętrznego prawa danego związku wyznaniowego. Zob. B. Rakoczy, Odpowiedzialność prawna zakonnika, s. 70-71.

${ }_{55}$ Zob. tenże, Prawo kanoniczne a reprezentacja osób prawnych Kościoła katolickiego problem przedstawicielstwa ustawowego i petnomocnictwa, „Prawo Bankowe” 2008, nr 1, s. 85.

${ }^{56}$ Zob. G. Radecki, Organy osób prawnych, s. 134; B. Rakoczy, Ustawa o stosunku państwa do Kościoła Katolickiego, s. 123. 
zgłoszonego statusu jest bardzo istotne z punktu widzenia umów prawa państwowego. Państwo nie bada prawidłowości procedury wewnętrznej, zatem ostatecznym dowodem obsadzenia stanowiska jest powiadomienie przekazane przez władzę kościelną. Ewentualne naruszenia zasad wewnętrznych nie mogą wpływać na skuteczność działania wyznaniowej osoby prawnej na gruncie państwowym.

Ograniczenia w rozporządzaniu majątkiem kościelnym przez osoby piastujące funkcje organów wyznaniowych osób prawnych chronić mają Kościół przed skutkami działań nieprzemyślanych ${ }^{57}$. Jednocześnie jednak ochrony wymagają kontrahenci kościelnych osób prawnych. Obecna linia orzecznictwa sądowego budzi wątpliwości specjalistów z zakresu prawa wyznaniowego. Rodzi także rozbieżności interpretacyjne, tworząc w przestrzeni prawa państwowego dodatkowe klauzule oparte o prawo kanoniczne. M. Pietrzak stwierdza: „Zapobiec temu może jedynie wprowadzenie publicznego rejestru wyznaniowych osób prawnych, zawierających wszystkie informacje, ograniczające uprawnienia osób reprezentujących wyznaniowe osoby prawne w obrocie cywilnoprawnym przez prawo wewnętrzne" 58 . Ze względu na dużą liczbę związków wyznaniowych działających na terenie Polski, różnorodność ich jednostek organizacyjnych i systemów zarządzania nimi konieczne jest stworzenia publicznego rejestru wyznaniowych osób prawnych, w którym zostałyby one skatalogowane wraz z określeniem kompetencji ich organów oraz wskazaniem osób pełniących funkcje reprezentacyjne. Stworzenie publicznie dostępnego rejestru ułatwi także funkcjonowanie związkom wyznaniowym, gdyż wewnętrzne regulacje będą obecne w systemie państwowym. Celem ujawnienia (a raczej doprecyzowania i podania do publicznej wiadomości) kanonicznych kompetencji organów konfesyjnych osób prawnych jest jednak przede wszystkim ochrona interesów osób trzecich ${ }^{59}$.

$\mathrm{W}$ ramach realizacji uprawnień wynikających z prawa dostępu do informacji publicznej autorzy niniejszego opracowania skierowali pytanie do poszczególnych wojewodów o formę i zakres prowadzo-

\footnotetext{
${ }^{57}$ Zob. A. Januchowski, Wybrane zagadnienia, s. 232.

${ }^{58}$ M. Pietrzak, Prawo kanoniczne, s. 32.

${ }^{59}$ Zob. A. Januchowski, Wybrane zagadnienia, s. 217-223.
} 
nej przez nich ewidencji wyznaniowych osób prawnych ${ }^{60}$. Z informacji pozyskanych od przedstawicieli urzędów wojewódzkich wynika, że niektóre $\mathrm{z}$ nich prowadzą rejestry, gromadząc dane wyznaniowych osób prawnych mających siedzibę na terenie ich właściwości. Ponadto rejestry te w poszczególnych przypadkach uwzględniają także dane związane z granicami terytorialnymi działalności wyznaniowych jednostek organizacyjnych, nazwiskami osób pełniących funkcje organów, adresami stron internetowych itd.

Każdego roku do urzędów wojewódzkich wpływa ok. 1509 wniosków o wydanie zaświadczeń o posiadaniu osobowości prawnej przez jednostki wyznaniowe. Większość z nich składana jest przez organy tychże jednostek, ale pojawiają się także wnioski od organów administracji publicznej, sądów oraz osób trzecich. Roczna liczba zmian w zapisach prowadzonych rejestrów waha się od 34 (woj. podkarpackie) do 202 (woj. małopolskie) dla każdego z województw prowadzących ewidencje. Urzędy zasadniczo nie prowadzą zestawień działających na ich terenie osób prawnych, wobec czego trudno jest oszacować ich ilość. Większość urzędów sprawy z zakresu wyznaniowych osób prawnych prowadzi w oparciu o dokumenty ułożone w teczkach aktowych posiadające kategorię archiwalną A. W województwie dolnośląskim, mazowieckim, podkarpackim oraz wielkopolskim zestawienia rejestrowane są także w formie elektronicznej (Wielkopolski Urząd Wojewódzki jest na etapie wdrażania aplikacji webowej przystosowanej do tego celu). Przedstawiciele niektórych urzędów przyznali, że w wydawaniu zaświadczeń posługują się publikacjami diecezjalnymi (schematyzmami), bez odniesień do posiadanych w swoich archiwach dokumentów informujących o zmianach w strukturze diecezji lub o osobach pełniących funkcję organów poszczególnych jednostek. Brak ustalonego jednakowego sposobu postępowania z danymi otrzymywanymi od wyznaniowych osób prawnych utrudnia funkcjonowanie tychże jednostek w przestrzeni publicznej.

${ }^{60}$ Badania przeprowadzone na przełomie sierpnia i września 2014 r. za pośrednictwem platformy ePUAP. 
Autorzy artykułu skierowali również wnioski do losowo wybranych naczelników urzędów skarbowych ${ }^{61} \mathrm{o}$ wskazanie podstaw ustalania granic terytorium parafii, które jest niezbędne do prawidłowego naliczenia zryczałtowanego podatku dochodowego od osób duchownych. Zgodnie z przepisami art. 43 ustawy z dnia 20 listopada $1998 \mathrm{r}$. o zryczałtowanym podatku dochodowym od niektórych przychodów osiąganych przez osoby fizyczne ${ }^{62}$, wysokość ryczałtu zależna jest między innymi od liczby mieszkańców parafii ${ }^{63}$. Z danych uzyskanych od urzędów skarbowych wynika, że źródłami wiedzy o granicach terenu parafii są: oświadczenia duchownych (ok. 45,5\% naczelników urzędów skarbowych posługuje się taką formą dowodową), informacje od organów gmin i miast (ok. 31,8\%; pojawia się tu pytanie o podstawy wiedzy tychże organów na temat granic terytorialnych parafii, same urzędy gmin nie potwierdzają prowadzenia jakichkolwiek zestawień dotyczących granic parafii), strony internetowe diecezji i parafii (ok. $31,8 \%$ ), oficjalne publikacje diecezjalne, czyli tzw. schematyzmy (ok. $13,6 \%$ ) oraz wojewodowie (ok. 4,5\%). Zgodnie z obowiązującymi przepisami, wojewodowie są jedynym organem, do którego władza kościelna ma ustawowy obowiązek zgłaszania granic parafii (art. 13 ust. 3 u.s.p.k.k.). Wiarygodne dowody w kwestii opodatkowania osób duchownych mogą zatem pochodzić jedynie z oświadczeń duchownych oraz z zaświadczeń od wojewodów. Jak jednak wykazano wcześniej, wojewodowie nie mają obowiązku prowadzenia rejestru granic terytorialnych parafii.

Wspomniane schematyzmy, czyli diecezjalne publikacje informacyjne, zawierające wykaz parafii i innych kościelnych jednostek organizacyjnych, wydawane są regularnie w polskich diecezjach. Problemem

${ }^{61}$ Badania przeprowadzono wśród naczelników 22 losowo wybranych urzędów skarbowych z terenu całej Polski w okresie od stycznia do sierpnia 2014 r. Odpowiedzi naczelników zostały dostarczone do autorów opracowania w formie pisemnej lub za pośrednictwem platformy ePUAP. Niektóre urzędy deklarują korzystanie z kilku form pozyskiwania danych, wobec czego suma przytoczonych wartości procentowych przekracza $100 \%$.

${ }^{62}$ Dz. U. Nr 144, poz. 930 z późn. zm.

${ }^{63}$ W tym miejscu warto zwrócić uwagę na wyrok Naczelnego Sądu Administracyjnego we Wrocławiu z dnia 24 stycznia 2002 r. (sygn. akt I SA/Wr 1893/99), w którym Sąd jednoznacznie stwierdza, że ustawodawca uzależnił wysokość ryczałtu od faktycznej liczby mieszkańców parafii, nie zaś od liczby osób zameldowanych na jej terenie. 
związanym z tymi publikacjami jest przede wszystkim ich nieaktualność - kolejne wydania ukazują się w regularnych zwykle odstępach czasu, zaś zmiany personalne lub organizacyjne na poziomie diecezji dokonane mogą być w dowolnym momencie (na przykład w związku z przejściem na emeryturę danego proboszcza). Ponadto schematyzmy nie zawsze uwzględniają stan prawny oparty o dokumenty państwowe. Dzieje się tak na przykład w sytuacji, gdy wewnętrzna struktura organizacyjna diecezji przekazuje kompetencje do zarządu nad cmentarzami organom kurialnym, zaś własność terenów cmentarzy ujawniona w księgach wieczystych wskazuje na parafię jako podmiot upoważniony do podejmowania działań związanych z zarządzaniem cmentarzem.

Przedstawione argumenty, pochodzące zarówno z orzeczeń sądowych, jak i wypowiedzi doktryny oraz praktyki administracyjnej, wskazują na konieczność podjęcia działań zmierzających do usprawnienia i ujednolicenia funkcjonowania wyznaniowych osób prawnych w przestrzeni publicznej oraz ochronę praw osób trzecich. Postulatem pojawiającym się już od kilku lat w wypowiedziach wybitnych przedstawicieli doktryny, jest stworzenie publicznego rejestru wyznaniowych osób prawnych.

\section{ZAKRES REJESTRU, KOMPETENCJE I OBOWIĄZKI ORGANÓW}

Głównym postulatem związanym z rejestrem jest objęcie go zasadą jawności zewnętrznej oraz ochrony zaufania osób trzecich, co wiąże się z możliwością otrzymania odpisów z niego przez wszystkich zainteresowanych. Postulat ten wysunęli M. Pietrzak, D. Walencik i A. Januchowski $^{64}$. Według projektu A. Januchowskiego, jednym z etapów tworzenia publicznego rejestru byłoby sporządzenie statutów kościelnych osób prawnych, określających zakres kompetencji organów. Pomysłodawca stwierdza: „nie ma przy tym podstaw do obawy, że prowadzenie takiego rejestru w jakikolwiek sposób pozwoli na ingerowania państwa w sprawy własne Kościoła. Treść statutu będzie bowiem zależała od

${ }^{64}$ Zob. A. Januchowski, Wybrane zagadnienia, s. 218; D. Walencik, Opinia prawna, s. 168; M. Pietrzak, Prawo kanoniczne, s. 32. 
decyzji właściwej władzy kościelnej, a możliwość kontrolowania treści statutu na etapie ujawniania zawartych w nim danych w rejestrze ograniczona mogłaby być jedynie do ich zgodności z polskim prawem"65.

Tworzenie dodatkowych statutów wydaje się jednak stanowić nadmierną trudność w określaniu granic działania organów kościelnych osób prawnych. Bardziej trafne wydaje się stworzenie formularzy i kategorii reprezentacji, w których można by było wprowadzić właściwe ograniczenia.

A. Januchowski postuluje także, aby rejestr zawierał informacje o kompetencjach organów, sposobie reprezentacji danej osoby prawnej oraz sposobie zaciągania zobowiązań majątkowych ${ }^{66}$. W przypadku osób prawnych Kościoła katolickiego (np. parafii) sprowadzałoby się to do określenia przez poszczególnych biskupów diecezjalnych (na podstawie przepisów prawa powszechnego i partykularnego) zakresu uprawnień proboszcza mieszczących się w granicach tzw. ,zwykłego zarządu" w materii dysponowania dobrami doczesnymi Kościoła (kan. 1281 KPK). Ponadto należy wskazać, w zakresie jakich czynności wymagana jest zgoda biskupa diecezjalnego (lub innego organu nadrzędnego) ${ }^{67}$.

Zgodnie $\mathrm{z}$ konstytucyjną zasadą równouprawnienia związków wyznaniowych, dane zawarte w rejestrze muszą dotyczyć wszystkich jednostek każdego z legalnie działających kościołów i innych związków wyznaniowych. Regulacje związane z reprezentacją są w ich prawie wewnętrznym mniej lub bardziej rozbudowane i szczegółowe ${ }^{68}$. Przygotowanie stosownych zestawień wymaga dużych nakładów pracy zarówno ze strony organu odpowiedzialnego za stworzenie rejestru, jak i organów związków wyznaniowych. Stworzenie dla przedstawicieli związków wyznaniowych odpowiednio przejrzystych procedur związanych $\mathrm{z}$ tworzeniem rejestru jest jednym z postulatów dotyczących powstania tejże bazy danych.

${ }^{65}$ A. Januchowski, Wybrane zagadnienia, s. 234-235.

${ }^{66}$ Tenże, Skuteczność prawa kanonicznego, s. 56.

${ }^{67}$ Zob. tenże, Wybrane zagadnienia, s. 212-213.

${ }^{68}$ Zob. M. Tomkiewicz, Zasada równouprawnienia kościołów i zwiąków wyznaniowych a zakres ich autonomii $w$ zarzadzaniu majątkiem na forum externum $w$ Polsce, ,Przegląd Religioznawczy” 2013, nr 4, s. 224. 


\subsection{TWORZENIE I PROWADZENIE REJESTRU}

Wydaje się, że organem najodpowiedniejszym do stworzenia i prowadzenia rejestru jest minister właściwy do spraw wyznań religijnych. Tym bardziej, że w założeniu nowy rejestr musi ściśle współpracować z istniejącym, ujawniającym związki wyznaniowe w ogólności działające na podstawie ustawy z dnia 17 maja 1989 r. o gwarancjach wolności sumienia i wyznania.

W literaturze pojawił się projekt, aby wpisy wyznaniowych osób prawnych umieścić w Krajowym Rejestrze Sądowym (dalej: KRS). Argumentem przemawiającym za takim rozwiązaniem jest fakt, że KRS już funkcjonuje i został zinformatyzowany, co czyni go dostępnym dla szerokiego grona odbiorców. Jego prowadzeniem zajmują się zaś niezależne sądy, przez co związki wyznaniowe otrzymują dodatkową gwarancję zachowania ich autonomii ${ }^{69}$. Zastosowanie drogi elektronicznej w dostępie do KRS oraz komunikacji z sądami ułatwia i przyśpiesza wymianę dokumentów między podmiotem rejestrowanym a rejestrującym ${ }^{70}$.

\subsection{KOMPETENCJE DO DOKONYWANIA WPISÓW}

Podmiotami kompetentnymi do zgłaszania wpisów wydają się być te organy, które mają prawo kreowania oraz znoszenia podległych sobie jednostek według prawa wewnętrznego Kościołów i związków wyznaniowych (w przypadku katolickich parafii - diecezja, zaś dla diecezji - Stolica Apostolska działająca przez nuncjaturę itd.). W przypadku Kościoła katolickiego, kompetencje organów zgłaszających powstanie, zmiany oraz ustanie osób prawnych zostały uregulowane w przytoczonych wyżej porozumieniach przedstawicieli Kościoła i Rządu. Zgłoszenie kompetencji najwyższych organów krajowych związków wyznaniowych podlegać powinno procedurze właściwej dla wpisu do

${ }^{69}$ Zob. A. Januchowski, Wybrane zagadnienia, 235; B. Rakoczy, Ustawa o stosunku państwa do Kościoła Katolickiego, s. 119-123.

${ }^{70}$ Zob. A. Kościółek, Elektroniczne czynności procesowe w sądowym postępowaniu cywilnym, Warszawa 2012, s. 322-325. 
istniejącego już rejestru kościołów i związków wyznaniowych prowadzonego obecnie przez Ministra Administracji i Cyfryzacji na podstawie u.g.w.s.w.

Podmiotami dokonującymi wpisów będą - w zależności od wybranego rozwiązania (nowy rejestr lub umieszczenie stosownych wpisów w ramach KRS) - właściwi terytorialnie wojewodowie i minister właściwy do spraw wyznań religijnych lub sądy rejestrowe. Zadaniem organów dokonujących wpisu w pierwszym przypadku ograniczyłoby się do wprowadzenia danych do systemu elektronicznego i przechowywaniu stosownej dokumentacji. W przypadku drugiego rozwiązania można także postulować sprawdzanie zgodności treści wpisów z obowiązującymi przepisami prawa państwowego.

\subsection{ZAKRES DOSTĘPNOŚCI DLA POSZCZEGÓLNYCH KATEGORII ODBIORCÓW}

Podstawowym postulatem związanym z rejestrem jest jego jawność. W dobie Internetu wydaje się, iż narzędziem najlepiej realizującym koncepcję publicznego dostępu do danych jest właśnie odpowiednia aplikacja dostępna w rozległej sieci komputerowej. Dostęp do bazy danych powinien zostać odpowiednio ograniczony. Zastanowić się trzeba, czy publikacja danych dotyczących osób piastujących funkcję organów jednostek, nie narusza ich prawa do ochrony danych osobowych.

Wobec powyższego przewidzieć należy w rejestrze ograniczenia dostępu. Dla organów zgłaszających wpis, dokonujących wpisu oraz wpisywanych dostęp ten bez wątpienia powinien być nieograniczony. Dane z pierwszym stopniem ograniczeń (w szczegółowym zakresie określonym przez organy zgłaszające treść wpisów) powinny być dostępne także dla organów administracji publicznej oraz sądów. Pozostałe dane z ewentualnym ograniczeniem danych osobowych osób piastujących funkcje organów (drugi stopień ograniczeń) powinny być powszechnie dostępne. W związku z przetwarzaniem danych osobowych, baza danych powinna zostać zgłoszona do Generalnego Inspektora Ochrony Danych Osobowych. 


\subsection{ZAKRES UJAWNIONYCH DANYCH}

Określenie zakresu danych objętych rejestrem stanowi trudność z uwagi na różnorodność rozwiązań praktycznych stosowanych w poszczególnych związkach wyznaniowych. Należy jednak wskazać pewien podstawowy zakres informacji, dzięki któremu rejestr będzie mógł funkcjonować w przestrzeni publicznej i chronić interesy związków wyznaniowych i osób trzecich.

\subsubsection{NAZWA}

Podstawową informacją, która domaga się ujawnienia w rejestrze, jest nazwa danej jednostki organizacyjnej. W praktyce zdarza się, że parafia funkcjonuje pod różnymi nazwami w różnych rejestrach ${ }^{71}$. Choć różnorodność jest tu niewielka, warto zadbać o ujednolicenie. Rozbieżności dotyczą zazwyczaj szyku wyrazów w nazwie, pisowni określającej denominację danej jednostki oraz określenie patrona (na przykład: „św. Jakub” czy „św. Jakub Apostoł”).

Obowiązujące reguły językowe dotyczące pisowni terminologii religijnej wskazują poprawny sposób zapisu, np. „Parafia Rzymskokatolicka pw. św. Andrzeja Apostoła w Lipnicy Murowanej”. Zapis ten z punktu widzenia administracyjnego jest bardzo uporządkowany zawiera się w nim określenie gatunkowe jednostki (parafia), jej przynależność denominacyjną, wskazującą także na właściwość stosowanego prawa wewnętrznego (rzymskokatolicka), określona została nazwa własna parafii (w postaci imienia jej patrona, czyli wezwania) oraz miejscowość, w której jednostka ma siedzibę. Wśród innych przykładów wymienionych wśród zasad pisowni, wskazać należy m.in.: „Gmina Wyznaniowa Żydowska w Krakowie”, „Parafia Prawosław-

${ }^{71}$ Nazwy ujawnione w urzędach skarbowych współbrzmią zazwyczaj z danymi z urzędów statystycznych, gdyż zaświadczenie o nadaniu numeru REGON jest wymagane do otrzymania numeru NIP. Jednakże w praktyce nie muszą być one jednakowe z nazwą parafii z aktu erekcyjnego oraz zaświadczenia przekazanego do właściwego wojewody. Podobnie instytucje bankowe, urzędy gmin i miast czy nawet wydziały sądowe odpowiedzialne za sprawy związane z prowadzeniem ksiąg wieczystych posługują się nazwami przestawionymi przez przedstawiciela kościelnej osoby prawnej, bazując zwykle na treści pieczęci. 
na Opieki Matki Bożej w Komańczy”, „Wojskowa Parafia Personalna św. Agnieszki w Krakowie" itd. ${ }^{72}$

\subsubsection{SIEDZIBA}

Istotną kwestią jest również precyzyjne określenie adresu siedziby osoby prawnej. W większości przypadków dotyczących większych związków wyznaniowych będzie ona tożsama $\mathrm{z}$ adresem nieruchomości należącej do danej osoby prawnej, w której rezyduje bądź zbiera się jej organ (zob. art. 41 k.c.). Określenie adresu siedziby ma swoje konsekwencje administracyjne w postaci ustalenia właściwości terytorialnej oraz możliwości odbierania dokumentów urzędowych.

\subsubsection{INNE DANE KONTAKTOWE ORAZ NUMERY W REJESTRACH}

Przy okazji tworzenia rejestru warto także uwzględnić inne względnie stałe dane identyfikacyjne lub komunikacyjne. Wskazać tu należy w szczególności Numer Identyfikacji Podatkowej oraz numer REGON. Można także dodać adres strony internetowej i poczty elektronicznej czy numer telefonu do siedziby.

\subsubsection{PRZYNALEŻNOŚĆ DENOMINACYJNA}

Niezmiernie ważną kwestią jest ujawnienie przynależności denominacyjnej danej jednostki. Ułatwia to dotarcie do odpowiednich źródeł prawa wewnętrznego lub statutów oraz weryfikację podstaw działania konkretnego związku wyznaniowego. Wyróżni także związki wyznaniowe spośród innych instytucji społecznych oraz podmiotów prawa.

W chwili obecnej w Rejestrze kościołów i innych związków wyznaniowych funkcjonują jednostki, których nazwy zawierają różnorakie określenia, w szczególności: Centrum, Gmina, Kościół, Ruch, Stowarzyszenie, Szkoła, Unia, Wiara, Wspólnota, Zakon, Zbór, Związek itd. ${ }^{73}$ Wszystkie one są związkami wyznaniowymi i mogą tworzyć swoje jednostki organizacyjne. Mimo nazwy „stowarzyszenie” nie muszą podlegać przepisom o działalności stowarzyszeń.

${ }^{72}$ Zob. R. Przybylska, W. Przyczyna, Pisownia słownictwa religijnego, Tarnów 2011, s. 43.

${ }^{73}$ Zob. M. Plisiecki, Wyznaniowa osoba prawna, s. 66-67. 


\subsubsection{TERYTORIALNE GRANICE DZIALANIA}

Wiele z jednostek wyznaniowych posiada charakter terytorialny, wiążący się z działaniem na konkretnym obszarze. Jego określenie jest istotne $\mathrm{z}$ punktu widzenia prawa wewnętrznego związków wyznaniowych i umożliwia stwierdzenie, czy dani wierni podlegają kompetencjom danej jednostki. Jak wykazano powyżej, określenie granic ma także istotne znaczenie dla przepisów podatkowych.

W przypadku jednostek o charakterze personalnym należy stosowną adnotację umieścić w rejestrze.

\subsubsection{ORGAN STANOWIĄCY}

Kolejnym elementem wpisu musi stać się określenie organu stanowiącego ustrój i istnienie osoby prawnej. Zgodnie z przepisami art. 2 u.s.p.k.k., „Kościół rządzi się w swych sprawach własnym prawem”, co oznacza, że tylko odpowiednie organy Kościoła mogą erygować jego jednostki. Niemożliwe jest zarejestrowanie parafii katolickiej przez kogokolwiek innego niż osoba upoważniona do tego przez władzę kościelną. Wydaje się, że w przypadku pozostałych związków wyznaniowych, kompetencje stanowienia jednostek są również zastrzeżone dla odpowiednich organów nadrzędnych. Organ stanowiący może mieć także prawo obsadzania stanowisk organu wpisywanego lub zatwierdzania osób wybranych czy prezentowanych do piastowania funkcji.

Oprócz określenia nazwy organu nadrzędnego (np. Arcybiskup Łódzki), warto wskazać także jego kompetencje (np. erygowanie, znoszenie, łączenie, podział, mianowanie organów, zatwierdzanie decyzji itd.). Niezmiernie istotne jest to w przypadku zakonnych osób prawnych, które zobowiązane są do przestrzegania szczególnych wewnętrznych regulacji kanonicznych ${ }^{74}$.

\subsubsection{ORGAN ZARZĄDZAJĄCY}

Osoba prawna dokonuje czynności przez działanie swojego organu. W zależności od charakteru osoby prawnej i jej przynależności konfesyjnej, organy te mogą być kolegialne lub monokratyczne. W przypadku organów kolegialnych należy ujawnić w rejestrze sposób podejmo-

\footnotetext{
${ }^{74}$ Zob. B. Rakoczy, Odpowiedzialność prawna zakonnika, s. 63-64.
} 
wania decyzji lub formę aktu, stanowiącego dowód jej podjęcia (np. uchwała podpisana przez dwie osoby z kolegium).

W zapisach rejestru ujawniona powinna zostać informacja o formie działania organu zarządzającego (jednoosobowy lub kolegialny), o jego nazwie ${ }^{75}$ (ewentualnie o nazwach funkcji pełnionych przez osoby wchodzące w skład gremium - prezes, proboszcz, członek rady itd.), a także imiona i nazwiska osób piastujących poszczególne funkcje wraz z ich numerami PESEL w celu umożliwienia ich identyfikacji. Dla umożliwienia weryfikacji umocowania organu w przeszłości, warto także zachować historię zmian wraz z datami powołania i odwołania osób pełniących funkcję organu.

\subsubsection{PRAWO REPREZENTACJI}

Aby spełnić podstawowy cel stworzenia i funkcjonowania rejestru, należy dokładnie opisać sposób reprezentacji osoby prawnej i wskazać granice jej kompetencji. Dotyczy to w szczególności możliwości składania oświadczeń woli w sprawach cywilnych, administracyjnych, podatkowych oraz sądowych (zarówno w sprawach spornych, jak i niespornych - na przykład w kwestii zmian w zapisach ksiąg wieczystych). Osoby prawne dokonują rozmaitych czynności i nadmierne uzależnianie ich legalności od woli organów stanowiących lub innych gremiów (np. przy składaniu deklaracji podatkowych czy przy składaniu wniosków o wydanie decyzji zezwalającej na prowadzenie prac przy obiektach zabytkowych stanowiących własność wyznaniowych osób prawnych) może spowodować zbędne utrudnienie działania osób prawnych i niepotrzebnie spowolnić bieg podstępowania. W katalogu czynności znaleźć się mogą także: wydawanie pełnomocnictw, reprezentacja przed organami administracji, inicjowanie spraw sądowych spornych itd.

${ }^{75} \mathrm{~W}$ obecnych zapisach ustawowych wymienione są nazwy organów wyznaniowych jednostek. Wśród nich wskazać można między innymi: Kapituła Generalna, Rada Kościoła, Sobór Lokalny, Metropolita, zarząd, Prezydium, Arcybiskup, Arcykapłanka, a także: Dialogos, Dyrektor, Imam, Naczelnik, Nauczyciel, ofiarnik, Prezydent, Starszy, Wielki Brat itd. Zob. M. Plisiecki, Wyznaniowa osoba prawna, s. 138-144. 


\subsubsection{PRAWO ZACIĄGANIA ZOBOWIĄZAŃ FINANSOWYCH}

Kolejną kompetencją organów osób prawnych jest zaciąganie zobowiązań finansowych. Można stworzyć w tym miejscu zamknięty katalog czynności, do których organ jest uprawniony bez konieczności uzyskania zezwolenia, wynikającego z prawa wewnętrznego związku wyznaniowego. Wśród czynności tych wskazać można do wyboru między innymi:

a) zawieranie umów o pracę (z ewentualnym ograniczeniem kwoty wynagrodzenia miesięcznego),

b) zawieranie umów zlecenia i o dzieło (i fakultatywnego określenia górnej granicy wynagrodzenia związanego z wykonaniem umowy),

c) zawieranie porozumień o świadczenia wolontarystyczne,

d) zawieranie umów związanych $\mathrm{z}$ prowadzeniem rachunku bankowego,

e) zaciąganie kredytów (w tym kredytów hipotecznych),

f) zakładanie lokat bankowych,

g) przyjmowanie darowizn i spadków,

h) nabywanie i sprzedaż nieruchomości i innych majątków (ograniczonych na przykład wartością transakcji lub faktem wpisu do rejestru zabytków) $)^{76}$,

i) zawieranie umów na wykonanie usług (np. remontowych, budowlanych, administracyjnych),

j) zawieranie umów związanych z najmem, dzierżawą, użyczeniem oraz dożywociem,

k) ustanawianie służebności na majątkach należących do wyznaniowej osoby prawnej (w tym służebności przesyłu),

1) zawieranie umów i podpisywanie dokumentów w sprawach związanych z dotowaniem działalności ze środków publicznych (na przykład przeznaczonych na remont zabytków czy działalność charytatywną),

m) wystawianie faktur,

${ }^{76}$ Zob. D. Walencik, Nabywanie dóbr doczesnych przez osoby prawne Kościoła katolickiego w świetle prawa polskiego i prawa kanonicznego, „Studia z Prawa Wyznaniowego” 2005 , t. 7 , s. $157-179$. 
n) tworzenie i wchodzenie w skład spółek,

o) ustanawianie fundacji (na gruncie państwowym w oparciu o przepisy ustawy z dnia 6 kwietnia 1984 r. o fundacjach ${ }^{77}$ ) itd.

\subsubsection{STATUS ORGANIZACJI POŻYTKU PUBLICZNEGO}

Przy rozważaniu ewentualnego wpisu do KRS, rozważyć należy możliwość uzyskania statusu organizacji pożytku publicznego (dalej: OPP) przez jednostki wyznaniowe. Zgodnie z art. 3 ust. 3 pkt 1 ustawy z dnia 24 kwietnia 2003 r. o działalności pożytku publicznego i wolontariacie $^{78}$, działalność pożytku publicznego może być prowadzona przez legalnie działające jednostki związków wyznaniowych, ,jeżeli ich cele statutowe obejmują prowadzenie działalności pożytku publicznego." Katalog tych zadań wskazany jest w art. 4 przytoczonej ustawy. Obejmuje on w szczególności: działalność charytatywną, wychowanie, promocję i organizację wolontariatu, działalności na rzecz rodziny, macierzyństwa, rodzicielstwa, upowszechniania i ochrony praw dziecka, przeciwdziałania uzależnieniom i patologiom społecznym itd. ${ }^{79}$

W KRS zarejestrowana jest katolicka parafia ${ }^{80}$ - kościelna osoba prawna będąca organizacją pożytku publicznego: „Parafia rzymsko-katolicka pod wezwaniem św. Jadwigi Królowej” (nr KRS: 0000208974). Została ona wpisana do rejestru dn. 15 czerwca 2004 r., na podstawie dekretu erekcyjnego parafii wydanego przez odpowiedniego arcybiskupa dn. 23 maja 1997 r. Zgodnie z wpisem KRS, nadzór nad parafią sprawuje biskup diecezjalny, zaś do reprezentacji upoważniony jest jednoosobowo zarząd, w skład którego wchodzi kierownik, będący jednocześnie proboszczem parafii. Ustanowiony został także trzyosobowy organ nadzoru w postaci rady. Parafia ta dn. 15 czerwca 2004 r. uzyskała status OPP, w związku z czym corocznie składa i publikuje sprawozdania finansowe i merytoryczne ze swojej działalności. Jako cele statutowe wymienia się:

${ }^{77}$ Tekst jedn. Dz. U. z 1991 r. Nr 46, poz. 203 z późn. zm.

${ }^{78}$ Tekst jedn. Dz. U. z 2010 r. Nr 234, poz. 1536 z późn. zm.

${ }^{79}$ Zob. M. Plisiecki, Wyznaniowa osoba prawna, s. 125-128.

${ }^{80}$ W KRS zarejestrowane są także fundacje czy stowarzyszenia zakładane przez Kościół oraz na przykład Caritas. Wspomniana parafia stanowi wyjątek w tej kategorii kościelnych osób prawnych. 
a) pomoc ludziom w stanie ubóstwa, zwłaszcza dzieciom,

b) organizowanie pomocy społecznej poprzez wsparcie materialne, rzeczowe lub pedagogiczne dla osób, które znalazły się w trudnej sytuacji materialnej,

c) świadczenie pomocy społecznej poprzez udzielanie wsparcia materialnego i rzeczowego,

d) dobroczynne wspieranie psychologiczne oraz świadczenie pomocy osobom potrzebującym ze szczególnym uwzględnieniem dzieci i młodzieży ${ }^{81}$.

Parafia wykazuje, że prowadzi działalność nieodpłatną w zakresie pomocy społecznej (PKD 88.99.Z) i działalności charytatywnej (przedmiot działalności: organizacja religijna; PKD 94.91.Z) oraz odpłatną w zakresie edukacji (PKD 85.10.Z).

Taka forma rejestracji parafii (nie zaś parafialnego stowarzyszenia czy fundacji) stanowi prawdopodobnie precedens w skali kraju. Przy konstruowaniu rejestru należy rozważyć celowość i procedury związane $z$ ewentualnym uzyskiwaniem statusu OPP przez parafie $i$ inne jednostki wyznaniowe.

\subsubsection{INNE UPRAWNIENIA}

Warto także sprecyzować inne uprawnienia organów wyznaniowych osób prawnych, w szczególności odnoszące się do sprawowania zarządu nad konkretnymi nieruchomościami. Wyznaniowe osoby prawne (zwłaszcza wspólnot chrześcijańskich) posiadają często prawo własności do cmentarzy wyznaniowych lub terenów rolniczych. Przy precyzowaniu uprawnień organów osoby prawnej należy zaznaczyć, czy organ ma prawo zarządzać samodzielnie prawem własności do cmentarza czy prawo to jest ograniczone wymaganą zgodą organu stanowiącego (np. biskupa diecezjalnego).

Jeśli przepisy wewnętrzne normują istnienie organów pomocniczych lub ciał doradczych (w szczególności rady ekonomicznej), należy także wskazać kompetencje tych ciał oraz wskazać sposób uwiarygodniania przez członków ich przynależności do poszczególnych gremiów (np.

${ }^{81}$ Zob. Sprawozdanie merytoryczne z działalności pożytku publicznego za 2013 rok, KRS: 0000208974, http://sprawozdaniaopp.mpips.gov.pl/ [dostęp: 25.08.2014]. 
w formie nominacji wydanej przez proboszcza lub biskupa, zawierającej ramowe daty kadencji, nazwisko i imię oraz numer PESEL osoby, jak również nazwę gremium i funkcji, jaką osoba w nim pełni).

\section{PODSUMOWANIE}

Analizując funkcjonowanie wyznaniowych osób prawnych w systemie prawa polskiego zauważyć należy ich szczególną pozycję, w pewnym stopniu podobną do statusu organizacji pożytku publicznego. Związki wyznaniowe i ich instytucje posiadające osobowość prawną cieszą się rozmaitymi uprawnieniami i działają w Polsce jako podmioty praw i obowiązków oraz strony różnorakich umów. Kompetencje organów jednostek konfesyjnych mogą być ograniczane przez prawo wewnętrzne danego związku wyznaniowego, zatem - dla ułatwienia obrotu prawnego - postulowane jest stworzenie publicznego rejestru, wspierającego działalność wyznaniowych osób prawnych oraz ich kontrahentów.

Podzielając przedstawione już w literaturze przez M. Pietrzaka, D. Walencika oraz A. Januchowskiego propozycje utworzenia takiego rejestru, autorzy niniejszego artykułu rozwijają i doprecyzowują zgłoszone koncepcje.

\section{BIBLIOGRAFIA}

Borecki P., Autonomia Kościołów i innych związów wyznaniowych we wspótczesnym prawie polskim, „Przegląd Religioznawczy” 2011, nr 3, s. 123-139.

Borecki P., Zasada równouprawnienia wyznań w prawie polskim, „Studia z Prawa Wyznaniowego" 2007, t. 10, s. 115-159.

Dadańska K. A., Działanie osoby prawnej, Warszawa 2006.

Gliszczyńska-Gniewek J., Śliwińska M., Zawieranie umów w praktyce bankowej. Parafia Kościoła katolickiego, Poznań 2012.

Góralski W., Pieńdyk A., Zasada niezależności i autonomii Państwa i Kościoła w Konkordacie polskim z 1993 r., Warszawa 2000. 
Grzybowski S., System prawa cywilnego, t. I, Wrocław 1985.

Januchowski A., Prawo kanoniczne a reprezentacja osób prawnych Kościoła katolickiego-problem przedstawicielstwa ustawowego i petnomocnictwa, „Prawo Bankowe” 2008, nr 1, s. 81-90.

Januchowski A., Skuteczność prawa kanonicznego w zakresie reprezentacji osób prawnych Kościoła katolickiego, „Rejent” 2007, nr 9, s. 49-67.

Januchowski A., Wybrane zagadnienia zwiazane z reprezentacja parafii przez proboszcza na gruncie prawa kanonicznego i polskiego, „Studia z Prawa Wyznaniowego" 2008, t. 11, s. 211-236.

Kidyba A., Kodeks cywilny. Komentarz. Część ogólna, t. 1, Warszawa 2009. Krukowski J., Warchałowski K., Polskie prawo wyznaniowe, Warszawa 2000. Krzemiński M., Znaczenie prawa kanonicznego dla określenia sposobu reprezentacji kościelnych osób prawnych (Glosa do wyroku SN z 27 lipca 2000 r.), „Prawo Bankowe” 2005, nr 10, s. 20-30.

Mezglewski A., Stolica Apostolska i Państwo Watykańskie jako podmioty prawa międzynarodowego, „Studia z Prawa Wyznaniowego” 2005, t. 8, s. 295-303.

Mezglewski A., Misztal H., Stanisz P., Prawo wyznaniowe, Warszawa 2008. Pietrzak M., Prawo kanoniczne w polskim systemie prawnym, „Państwo i Prawo" 2006, nr 8, s. 16-31.

Pietrzak M., Prawo wyznaniowe, Warszawa 2010.

Plisiecki M., Wyznaniowa osoba prawna w prawie polskim, Warszawa 2013.

Pyziak-Szafnicka M., Kodeks cywilny. Część ogólna. Komentarz, Warszawa 2009.

Radecki G., Organy osób prawnych Kościoła katolickiego w Polsce, „Rejent” 2003, nr 7-8, s. 127-155.

Rakoczy B., Odpowiedzialność zakonnika załatwiajacego sprawy zakonnej osoby prawnej, „Przegląd Prawa Wyznaniowego” 2009, nr 1, s. 63-73.

Stanisz P., Proboszcz jako reprezentant parafii rzymskokatolickiej $w$ stosunkach cywilnoprawnych, w: Prawo państwowe a prawo wewnętrzne związków wyznaniowych. Pamiętnik VII Zjazdu Katedr i Wykładowców Prawa Wyznaniowego, Gniezno 11-12 IX 2010, red. K. Krasowski, M. Materniak-Pawłowska, M. Stanulewicz, Poznań 2010, s. 191-200.

Tomkiewicz M., Zasada równouprawnienia kościołów i zwiąków wyznaniowych a zakres ich autonomii w zarzadzaniu majątkiem na forum externum w Polsce, „Przegląd Religioznawczy” 2013, nr 4, s. 215-227. 
Walencik D., Nabywanie dóbr doczesnych przez osoby prawne Kościoła katolickiego $w$ świetle prawa polskiego i prawa kanonicznego, „Studia z Prawa Wyznaniowego" 2005, t. 7, s. 157-179.

Walencik D., Opinia prawa w sprawie nabycia osobowości prawnej przez dom zakonny Zgromadzenia Sióstr Najświętszej Rodziny z Nazaretu z siedziba w Żarkach, „Przegląd Prawa Wyznaniowego” 2011, nr 3, s. 259-268.

Wyznania religijne, stowarzyszenia narodowościowe $i$ etniczne $w$ Polsce 2009-2011, red. P. Ciecieląg, Warszawa 2013.

Zoll F., Prawo cywilne. Część ogólna, Warszawa 2011.

\section{THE REGISTER OF DENOMINATIONAL LEGAL ENTITIES \\ - THE SELECTED ISSUES ON THE EXAMPLE \\ OF CATHOLIC CHURCH UNITS}

\section{Summary}

Organizational units of Churches and religious associations may receive legal personality on the basis of the Polish law. This privilege enables them to function freely in the public space. According to the concept adopted in Poland, legal persons act through their organs. The domestic law of the Catholic Church introduces a number of restrictions in regard to the competences of particular organs, which causes difficulties in the legal turnover. What has started to become the subject of the court's rulings has been the fact of taking actions by the church's legal person to which he has not been authorized on the basis of the canonic law. The sentences issued in these matters have led to a discussion on the doctrine. The solution of the problem is to make the competences of particular legal persons and their organs public, which will ensure the security of the turnover. M. Pietrzak, D. Walencik and A. Januchowski, the authors of the articles, postulate the creation of the public register of denominational legal persons. The authors of the article develop this concept and provide an outline for this register - it would contain information about the denominational legal person's name, the address of residence and identification numbers. Moreover, what should be revealed is denominational belonging, the area of action, the data referring to the decision making organ (superior) and the data of the managing organ (executive). The article also presents an exemplary catalogue of competences connected with representation law and 
incurring financial obligations which should be listed in the register. The possibility of giving the status of a public utility organization has also been tackled.

Ttumaczenie: Eliza Strojewska

Key words: denominational legal person, canonic law, register

Słowa kluczowe: wyznaniowa osoba prawna, prawo kanoniczne, rejestr 